\title{
MENINGKATKAN PENGETAHUAN CARA SENAM OTAK UNTUK KONSENTRASI DAN DAYA INGAT PADA ANAK USIA 5-12 TAHUN
}

\author{
Siska Karmelina ${ }^{1}$, Ria Setiasari ${ }^{1}$, Ike Pudji Wahyuningsih ${ }^{1 *}$, Nurseha ${ }^{1}$, Ana \\ Febrianti $^{1}$, Djati aji Nurbiantoro ${ }^{1}$, Hesti Setiawati ${ }^{1}$, Castirih ${ }^{1}$, Ilham Efendi ${ }^{1}$, \\ Ola Filianata ${ }^{1}$, Yanti Susilawati ${ }^{1}$, Fajar Muharom ${ }^{1}$, Erna Yuliana ${ }^{1}$, Mia \\ Amalia $^{1}$, Yudi Sulistyo ${ }^{1}$ \\ ${ }^{1}$ Stikes Yatsi Tangerang \\ Email Koresnpondesi : ikepudji26@gmail.com
}

\begin{abstract}
ABSTRAK
Senam otak atau brain gym adalah serangkaian latihan gerakan tubuh yang sederhana. Gerakan itu dibuat untuk merangsang otak kiri dan kanan (dimensi lateralis), meringankan atau merelaksasikan belakang otak dan bagian depan otak (dimensi pemfokuskan), merangsang sistem yang terkait dengan perasaan/emosional, yakni otak tengah (limbik), serta otak besar (dimensi pemusatan) dan bermanfaat menigkatkan kemampuan berbahasa, konsentrasi, daya ingat meningkat, menjadi lebih bersemangat, lebih kreatif dan efesien, serta merasa lebih sehat. Dengan latihan senam otak, maka sangat berguna untuk meningkatkan keseimbangan dinamis selain itu juga dapat meningkatkan koordinasi dan konsentrasi yang baik. Tujuan penelitian ini adalah mengetahui bagaimanakah pengaruh senam otak terhadap konsentrasi dan daya ingat pada anak. Penelitian ini menggunakan metode presentasi powerpoint dan video senam otak pada klien dan keluarga. Hasil dari presentasi dan demonstrasi yang dilakukan adalah sebanyak $75 \%$ peserta mengetahui dan dapat melakukan senam otak dan akan mempraktekkan pada eluarganya dirumah.
\end{abstract}

Kata kunci: Senam Otak, Konsentrasi

\section{ABSTRACT}

A brain gym or brain gym is a series of simple body exercises. The movement is made to stimulate the left and right brain (lateral dimension), lighten or relax the back of the brain and the front part of the brain (the focal dimension), stimulate systems related to feelings / emotions, namely the midbrain (limbic), and the cerebrum (concentration dimension) and is useful for increasing language skills, concentration, increased memory, being more enthusiastic, more creative and efficient, and feeling healthier. With brain exercise exercises, it is very useful to improve dynamic balance besides that it can also improve good coordination and concentration. The purpose of this study was to determine how the influence of brain exercise on concentration and memory in children. This study uses a PowerPoint presentation method and video brain exercise to clients and families. The results of the presentations and demonstrations carried out were that as many as $75 \%$ of the participants knew and were able to do brain exercises and would practice them in their families at home.

Keywords: Brain Exercise, Concentration 


\section{PENDAHULUAN}

Tahapan awal pada perkembangan manusia berada pada masa dini, dimana semua aspek berkembang sangaat baik. Maka di tahap ini dibutuhkan stimulasi yang tepat. Pertumbuhan dan perkembangan manusia sangat penting yaitu pada masa usia anak (Suryana, Pendidikan Anak Usia Dini, 2013). Usia dini merupakan masa awal dalam proses perrkembangan yang pesat untuk kehidupan berikutnya. Anak memiliki karakteristik sendiri yang membeda antara satu dengan yang lainnya (Yulsyofriend, 2013).

Melalui pendidikan dapat menyonsong potensi yang ada pada diri anak. Mulyasa menjelaskan anak usia dini mempunyai karakter tersendiri seperti, fisik, psikis, sosial, moral spiritual maupun emosional (Mulyasa, 2012). Pendidikan PAUD dibutuhkan anak dalam mengupayakan perkembangan. Susanto menjelaskan bahwa pendidikan anak usia dini merupakan suatu bentuk pembelajaran untuk memfokuskan dasar pertumbuhan yang tepat dan tahap perkembangan yang dilalui anak usia dini (Susanto, 2017). Suryana menjelaskan tujuan dari pendidikan anak usia dini membantu peletak dasar perkembangan sikap, perilaku, pengakuan, keterampilan, dan kreativitas yang diperlukan oleh anak (Suryana, Pendidikan Anak Usia Dini Stimulasi \& Aspek Perkembangan Anak, 2016). Berbagai media pembelajaran dan kegiatan yang dapat memberikan rangsangan terhadap perkembangan anak. Senam otak merupakan salah satu kegiatan yang dapat menstimulasi terutama pada perkembangan kognitif, motorik, dan sosial emosional anak. Senam otak (Brain Gym) dipopulerkan oleh Paul E. Dennison, Dr Phill dengan istrinya Gail E. Dennison yang merupakan pelopor pendidikan di Amerika Serikat dalam penerapan senam otak.

Dennison \& Dennison (Priambodo, 2017) senam otak dapat mengimbangi antara otak yang berkaitan dengan fisik dan psikis. Kegiatan senam otak memiliki peran penting dalam pendidikan anak. Beberapa alasan pentingnya melaksanakan senam otak antara lain, sulit belajar nerusaha terlalu keras, sehingga membuat stress pada anak, kinerja integrasi otak melambat, dan membuat bagian otak tertentu kurang berfungsi dengan baik, bagian belakang otak menerima informasi sulit diekspresikan, membuat kurang fokus dan stress yang mengakibatkan semangat belajar berkurang, dan kurang belajar dan berusaha membuat prestasi menurun dan perasaan tidak berhasil semakin bertambah, akibatnya sulit untuk keluar dari lingkungan negatif tersebut (Sukri \& Sukri, 2013).

Berdasarkan penjabaran di atas serta awal pengamatan yang peneliti lakukan di Taman Kanak-kanak \& Playgroup kreatif primagama Padang, peneliti menemukan keunikan dari Taman Kanak-kanak yaitu memiliki rancangan kegiatan program- program sendiri yang membedakan dari Taman Kanak-kanak pada umumnya seperti, berenang, fiel trip berdasa rkan tema, dan pelaksanaan kegiatan senam otak yang sudah terancang dengan baik. Peneliti memfokuskan penelitian pada senam otak karena Taman Kanak-kanak ini sudah menerapkan kegiatan senam otak sejak tahun 2008. Pelaksanaan kegiatan senam otak ini sudah terjadwal dalam perencanaan yaitu dilaksnakan pada hari selasa dan kami yang tertera dalam program rancangan pembelajaran harian (RPPH). Berdasarkan observasi tersebut peneliti tertarik untuk meneliti kegiatan senam otak di TK \& PlayGroup Kreatif Primagama Padang. 


\section{MASALAH}

Pentingnya konsentrasi dan daya ingat anak usia 5-12 tahun (anak usia sekolah) agar dapat tumbuh dan berkembang dengan baik terutama di era pandemic yang mengharuskan anak selalu berinteraksi dengan gadget, oleh karena itu dilakuka penyuluhan senam otak untuk anak usia 5-12 tahun oleh kelompok.

\section{METODE}

\section{a. Tahap Persiapan}

Tahap ini dimulai dengan pembuatan proposal kegiatan, pembuatan materi penyuluhan dan pembuatan link dengan media Google Meet.

b. Tahap Pelaksanaan

Pelaksanaan dilakukan ketika semua peserta acara sudah masuk di link Google Meet. Acara dibuka oleh MC dan dilakukan sambutan dan tujuan kegiatan oleh ketua panitia. Kemudian dilakukan pemaparan materi melalui presentasi powerpoint kemudian dilajutkan dengan pemutaran video senam otak. Panitia dan peserta ikut mendemonstrasikan senam otak. Setelah selesai dilakukan sesi Tanya jawab.

\section{c. Evaluasi}

1) Struktur

Kegiatan diikuti oleh 10 anak dan orangtua masing-masing anak. Anak- anak yang mengikuti acara kegiatan berkisar umur 5-12 tahun. Acara kegiatan berjalan lancer dan diikiuti dengan baik oleh peserta. Dari 10 orang anak yg aktif sekitar 6 orang, 4 orang anak lainnya pasif,

2) Proses

Pelaksanaan kegiatan dimulai pukul 14.00 sampai 15.00 wib.

Melalui link Google Meet.

\section{HASIL DAN PEMBAHASAN}

Hasil dari kegiatan senam otak atau respon klien tentang kegiatan senam otak yang telah dilakukan secara bersama - sama. Klien diminta menjelaskan kembali tentang tahap - tahap gerakan senam otak yang telah dilakukan sebelum melakukan kegiatan senam otak sebanyak 10 orang berbagai usia. Peserta yang aktif hanya 6 orang yang tidak aktif 4 orang. Evaluasi dilakukan setelah kegiatan senam otak atau setelah implementasi dilakukan.

Peserta tampak aktif antusias mengikuti penyuluhan setelah melakukan kegiatan sebanyak 10 orang dengan rentang usia 5-12 tahun. Peserta yang aktif hanya 6 orang yang tidak aktif 4 orang. Ketika diajukan beberapa pertanyaan mengenai materi yang telah disampaikan, peserta dapat menjawab dan mengulanginya kembali. Kelompok menilai kegiatan terlaksana dengan efektif dan berlangsung dengan baik dilihat dari ketepatan pemilihan materi dengan sasaranya dan keaktifan peserta, namun kurangnya ketepatan waktu, dilihat dari alokasi penjadwalan pelaksaan tidak sesuai dengan waktu kegiatan. 
Tabel 4.1 Hasil Kegiatan

\begin{tabular}{|c|c|c|c|c|}
\hline NO & $\begin{array}{l}\text { NAMA } \\
\text { ANAK }\end{array}$ & AKTIF & TIDAK & HASIL \\
\hline 1 & An.F(5) & $\mathrm{Ya}$ & & $\begin{array}{l}\text { Melakukan kegiatan dan } \\
\text { bertanya }\end{array}$ \\
\hline 2 & An.A(7) & & Tidak & $\begin{array}{l}\text { Cenderung diam dan tidak } \\
\text { menhikuti senam }\end{array}$ \\
\hline 3 & $A n \cdot A(5)$ & $\mathrm{Ya}$ & & Aktif melakukan senam \\
\hline 4 & An.N(9) & Ya & & $\begin{array}{l}\text { Melakukan kegiatan dan } \\
\text { aktif bertanya }\end{array}$ \\
\hline 5 & An.I(10) & Ya & & $\begin{array}{l}\text { Melakukan kegiatan dan } \\
\text { aktif bertanya }\end{array}$ \\
\hline 6 & An.M(8) & & Tidak & Cenderung diam \\
\hline 7 & $A n \cdot A(5)$ & & Tidak & Cenderung diam \\
\hline 8 & An.S(5) & Ya & & $\begin{array}{l}\text { Aktif mengikuti hingga } \\
\text { selesai }\end{array}$ \\
\hline 9 & An.N(9) & Ya & & $\begin{array}{l}\text { Melakukan kegiatan dan } \\
\text { aktif bertanya }\end{array}$ \\
\hline 10 & An.M(7) & ya & & $\begin{array}{l}\text { Anak aktif dan mengikuti } \\
\text { hingga selesai }\end{array}$ \\
\hline
\end{tabular}
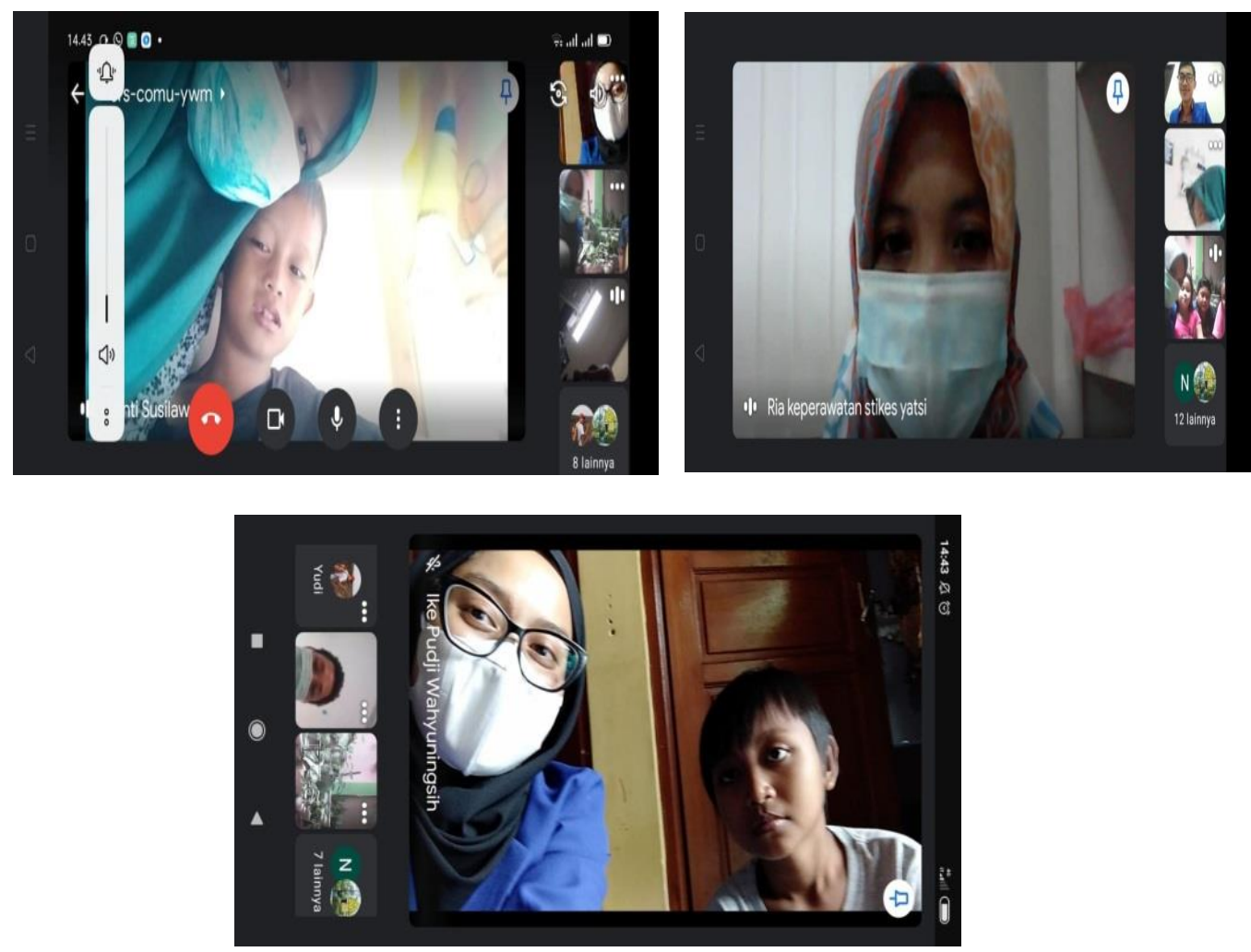

Gambar. Pelaksanaan Kegiatan 


\section{KESIMPULAN}

Kegiatan penyuluhan ini tentang senam otak yang dilakukan oleh orang tua anak yang di laksanakan pada Bulan januari Tanggal 27 Tahun 2021 di rumah masing-masing klien anggota kelompok. Kegiatan ini bersifat penyuluhan kepada masyarakat. Kegiatan ini dimaksudkan untuk memberikan informasi dan penjelasan kepada orang tua dan klien mengenai senam otak pada anak. Tahapan pelaksanaan merupakan tahap inti dari pelaksanaan kegiatan. Pada pelaksanaan kegiatan tersebut terlebih dahulu dilakukan penjelasan mengenai senam otak serta menjelaskan mengenai senam otak.

\section{DAFTAR PUSTAKA}

Anima, Indonesian Psycchological Journal. Vol. 17. Abu Ahmadi \& Supriyono. (2013). Psikologi Umum. Jakarta: Rineka Cipta

Afiatin, T. (2001). Belajar Pengalaman Untuk Meningkatkan Memori No. 1.26-35

Akbarjono, A. I. W., \& Saputra, A. (2019). Senam otak (brain gym) meningkatkan memori jangka pendek (short memory) pada anak tuna grahita ringan usia 8-9 tahun. Institut Agama Islam Negeri Bengkulu.

Astuti, R. C. (2015). Pengaruh senam otak terhadap memori jangka pendek siswa sekolah dasar di SD Negeri 34 Pontianak kota tahun 2014. Universitas Tanjung Pura.

Dennison, P. E. (2003). Brain gym (senam otak). PT Grasindo.

Desiningrum, D. R. (2016). Terapi senam otak untuk menstimulasi kemampuan memori jangka pendek pada anak autis. Jurnal Psikologi, 43(1), 30-41.

Desiningrum, D. R., \& Febriana, I. (2010). Menstimulasi kemampuan kognitif (atensi, fokus pemahaman, konsentrasi, dan memori jangka pendek) anak autis melalui terapi senam otak. Universitas Diponegoro. Donczik, J. (2001). Konnen edukinestetishe ubungen (brain gym). Brain Gym Hournal, XV, 297-305.

Drabben-Thiemann, G., Hedwig, D., Kenklies, M., Blogberg, V., Marahrens, A., Marahrens, G., \& Hager, K. (2002). The effect of brain gym on the cognitive performance of alzheimer's patients. Brain Gym Journal, 16(1).

Gea, S. R. (2016). Pengaruh brain gym (senam otak) terhadap memori jangka pendek penyandang tunagrahita ringan di SDLB-C Dharma Asih Pontianak. Jurnal ProNers, 3(1).

Maclin. (2007). Cognitive Psychology. Jakarta: Erlangg. 